\title{
On three species of Hogna Simon, 1885 (Aranei: Lycosidae) from the Near East and Central Asia
}

\author{
Три вида Hogna Simon, 1885 (Aranei: Lycosidae) с Ближкнего \\ Востока и из Џентральной Азии
}

\author{
Dmitri V. Logunov \\ Амитрий В. Аогунов
}

The Manchester Museum, The University of Manchester, Oxford Road, Manchester M13 9PL, UK.
E-mail: dmitri.v.logunov@manchester.ac.uk

KEY WORDS: Afghanistan, Alopecosa, Araneae, Arctosa, Canary Islands, Hyaenosa, (re)description, spiders, the UAE.

КЛЮЧЕВЫК СЛОВА: Афганистан, Alopecosa, Araneae, Arctosa, Канарские острова, Hyaenosa, (пере) описание, пауки, ОАЭ.

ABSTRACT. The paper presents a diagnosis and description of a new wolf spider Hogna ackermanni sp.n. ( $\mathrm{O}^{\top}+$ ) from Afghanistan, and redescriptions of two Near East Hogna species that to date have been known from the original descriptions only: viz., $H$. sinaia Roewer, 1959 (+) from Egypt (Sinai) and $H$. effera (O. Pickard-Cambridge, 1872) from Israel. Distribution of all three species is mapped. The lectotype $\left(\mathrm{O}^{7}\right)$ is designated for $H$. effera. Two new combinations are proposed: Arctosa afghana (Roewer, 1960) comb.n. (ex Hogna), and Hogna effera (O. Pickard-Cambridge, 1872), comb.n. (ex Hyaenosa). Two new synonyms are proposed: Tarentula iaffa Strand, 1913 syn.n. (+) from Israel and Geolycosa altera Roewer, 1955, syn.n. (+) from Iran; both with $H$. effera. Additionally, comments on the taxonomy and distribution of the Mediterranean Hogna ferox (Lucas, 1838) are given; this species is illustrated based on the female from Gran Canaria.

How to cite this article: Logunov D.V. 2020. On three species of Hogna Simon, 1885 (Aranei: Lycosidae) from the Near East and Central Asia // Arthropoda Selecta. Vol.29. No.3. P.349-360. doi: 10.15298/ arthsel. 29.3.08

РЕЗЮМЕ. В статье даны диагноз и описание нового вида пауков-волков Hogna ackermanni sp.n. $\left(\bigcirc^{7}+\right)$ из Афганистана и переописания двух ближневосточных видов Hogna, которые к настоящему времени известны только по первоописаниям: H. sinaia Roewer, 1959 (†) из Египта (Синай) и H. effera (О. Pickard-Cambridge, 1872) из Израиля. Распространение всех трех видов прокартировано. Обозначен лектотип $\left(\sigma^{7}\right)$ для H. effera. Предложены две новые комбинации: Arctosa afghana (Roewer, 1960) comb.n. (ex Hogna), и Hogna effera (O. Pickard-Cambridge, 1872), comb.n. (ex Hyaenosa). Предложены два новых синонима: Tarentula iaffa Strand, 1913 syn.n. (†) из Израиля и Geolycosa altera Roewer, 1955, syn.n.
(+) из Ирана; оба с H. effera. Дополнительно прокомментированы таксономия и распространение средиземноморского вида Hogna ferox (Lucas, 1838); также даны рисунки самки этого вида с Гран-Канарии.

\section{Introduction}

The genus Hogna Simon, 1885 is one of the most diverse and least studied genera of wolf spiders, currently accounting for 237 species names [WSC, 2020] of which the majority ( 170 species, $71 \%$ ) remain known from the original, usually old and poorly illustrated descriptions. Indeed, for a long time the genus Hogna has been used as a 'dumping ground' for wolf spiders that could not be satisfactory placed in other genera. Only recently, attempts have been made to bring some clarity to a number of taxa currently assigned to Hogna (e.g., Brady [2012]; Logunov \& Ponomarev [2020]; etc.). Even the type species of this genus - Hogna radiata (Latreille, 1817) - remains poorly known and inadequately illustrated (e.g., Fuhn \& Niculescu-Burlacu [1971: fig. 95, sub Lycosa r.]; Pepe, [2005: figs 6-8]) suggesting that two or more species could be present under this name (see Brady [2012: 182]). Both the genus Hogna and its type species are in urgent need of a thorough revision.

However, the three species treated in the present paper are true members of Hogna. Based on the key to European genera of Lycosidae [Nentwig et al., 2020], the studied species share the following diagnostic characters of Hogna: they are medium to large spiders (10$14 \mathrm{~mm}$ body length in males and $13-19 \mathrm{~mm}$ in females). The midline band of the carapace lacks dark markings (Figs 8-10, 31, 32). The cheliceral retromargin has three teeth (Figs 15, 41). The AME/clypeus ratio is $1.2-1.6(>0.7$, as expected). Macrosetae are present on the cymbial apex (arrowed in Fig. 14). In 


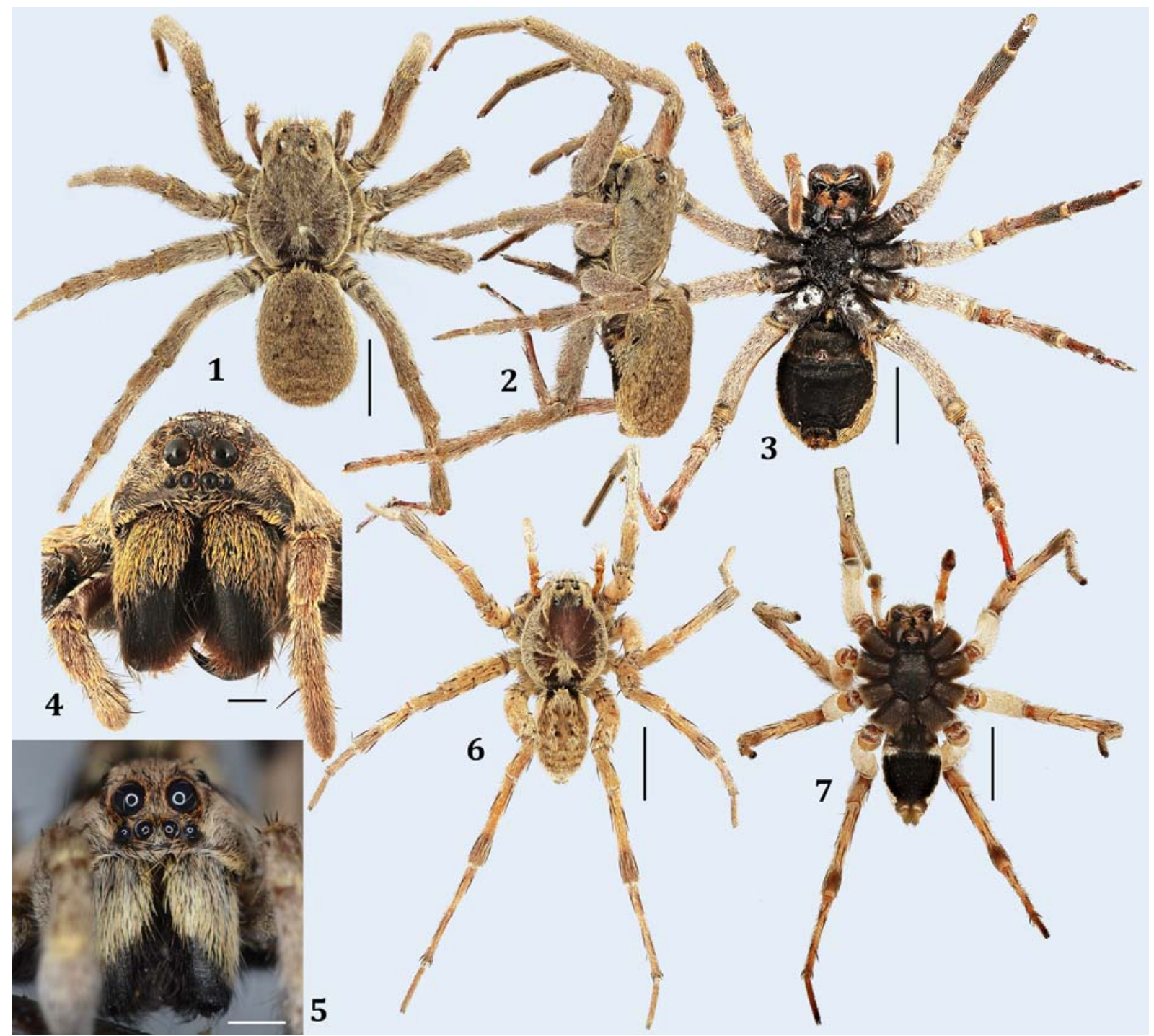

Figs 1-7. General appearance of Hogna ackermanni sp.n. (1-4, holotype + , 5-7, paratype $\bigcirc^{7}$ from MMUE): 1, 6 - body, dorsal view; 2 - ditto, lateral view; 3, 7 - ditto, ventral view; 4, 5 - ditto, frontal view. Photo 5, credit to G. Ackermann (Erlinsbach, Switzerland). Scale bars: $1 \mathrm{~mm}(4,5), 5 \mathrm{~mm}(1-3,6,7)$.

Рис. 1-7. Общий вид Hogna ackermanni sp.n. (1-4, голотип +, 5-7, паратип о из MMUE): 1, 6 - тело, вид сверху; 2 - то же, вид сбоку; 3, 7 - то же, вид снизу; 4, 5 - то же, вид спереди. Фото 5, признательность Г. Акерманну (Эрлинсбах, Швейцария). Масштаб: 1 мм (4, 5), 5 мм $(1-3,6,7)$.

the female epigyne the septal pedicel is equal to or usually longer than the septal base (Figs 22, 26, 39) and the male palp has a single, sickle-shaped synembolus (Figs 16, 17, 36). It should be noted that although the combination of diagnostic characters presented above is probably adequate to define the genus Hogna in the current state of our knowledge, not all of them are true synapomorphies, likely representing plesiomorphic states for a wider grouping of lycosine genera. Indeed, further research is required to adequately define the genus.

Two of the species redescribed below - Lycosa effera O. Pickard-Cambridge, 1872 and H. sinaia Roewer, 1959 - have never been re-examined after their original descriptions [Pickard-Cambridge, 1872; Roew- er, 1959]. The only attempt to re-examine and illustrate L. effera was made by Roewer [1960a: figs 255a-c] who, despite claiming that he saw the type series, illustrated a female (apparently from Libya) [Ibid: fig. 255a] that belongs neither to this species, nor to Hogna. Earlier, Roewer [1955a] assigned this species to the genus Hyaenosa Caporiacco, 1940, but in my opinion this decision was poorly justified; see below under 'Comments' on H. effera.

Based on WSC [2020], the new species described below is the third Hogna species known from Afghanistan. Two others were described by Roewer [1960] from female holotypes: Trochosula afghana Roewer, 1960 (now in Hogna) and H. bhougavia Roewer, 1960. The holotype of the former species is kept at the Senck- 

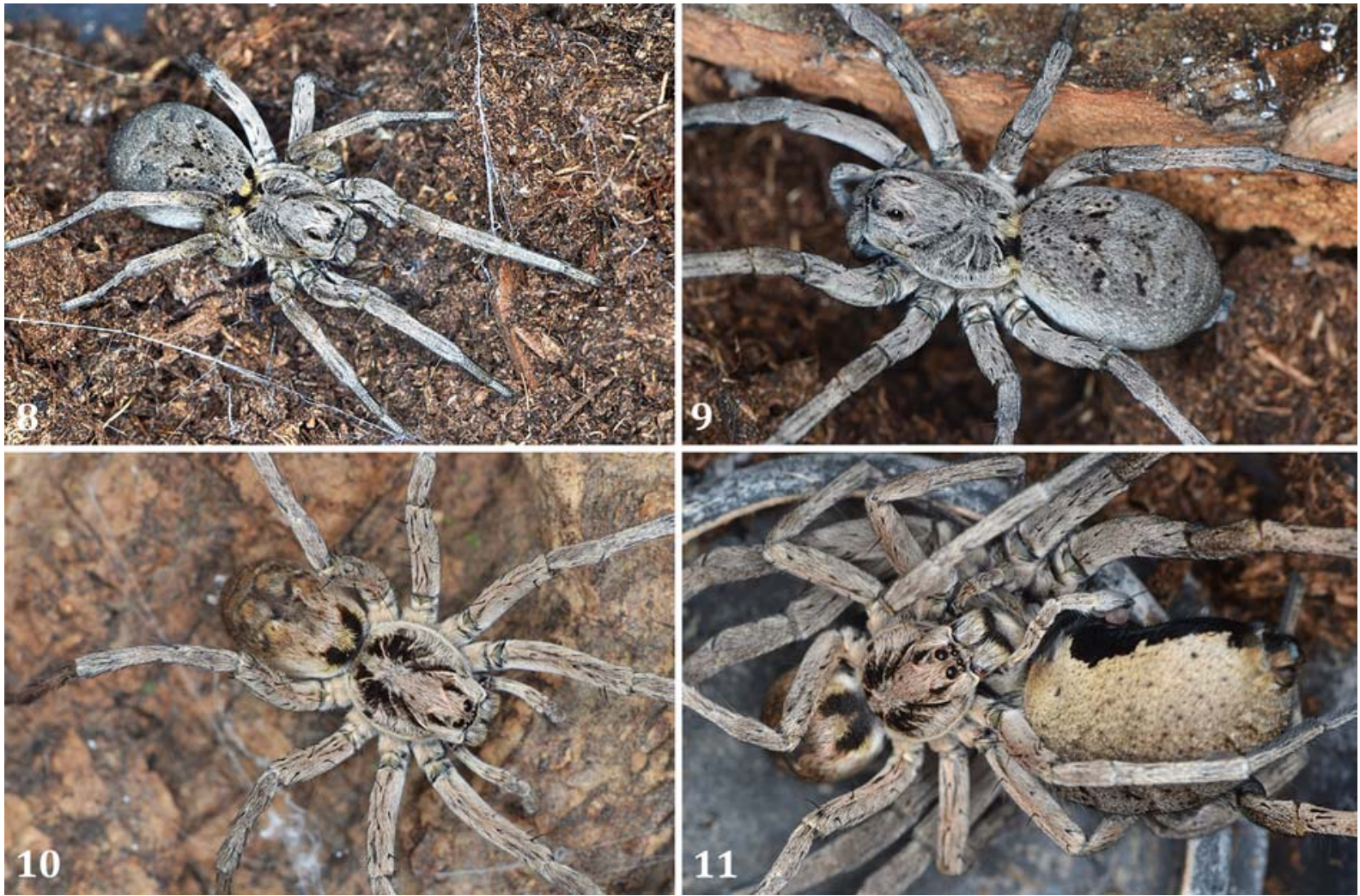

Figs 8-11. Live captive-bred specimens of Hogna ackermanni sp.n: 8, 9 - female, dorsal view; 10 - male, dorsal view; 11 - mating pair (male on the left). Credits to G. Ackermann (Erlinsbach, Switzerland).

Рис. 8-11. Живые лабораторные экземпляры Hogna ackermanni sp.n: 8, 9 — самка, вид сверху; 10 - самец, вид сверху; 11 спаривающаяся пара (самец слева). Признательность Г. Акерманну (Эрлинсбах, Швейцария).

enberg Nature Museum and Research Institute (SMFM, 9913329). It has been re-examined by the author and appears to actually belong to Arctosa C.L. Koch, 1847, being similar to the Palaearctic A cinerea (Fabricius, 1777) and $A$. leopardus (Sundevall, 1833) (cf. fig. 22a in Roewer [1960] with illustrations in Nentwig et al. [2020] or figs 201i, 204e in Almquist [2005]). The epigyne of $H$. afghana have all the characteristic features of Arctosa: viz., the epigynal atrium being divided by a hairy septum and copulatory openings sitting at posterio-lateral rims (seen as sclerotized nodes [Roewer, 1960: fig. 22a]). Although a clarification of the taxonomic validity of $H$. afghana lies outside the scope of the present study, it seems reasonable to propose a new combination for this species: Arctosa afghana (Roewer, 1960) comb.n.

The female holotype of $H$. bhougavia, as well as that of Megarctosa bamiana Roewer, 1960 (also from Afghanistan), were deposited in the collection of the Biological Museum of Lund University (Sweden) but could not be found there and seem to no longer exist. They were likely to have been destroyed together with other materials collected by Lindberg during a car crash in 1962 (Lars Lundqvist, pers. comm., 8 October 2019). Although the taxonomic status and validity of these two names cannot be verified at present, based on the original illustrations by Roewer [1960: figs 15a, 21a] none of them is a member of Hogna.

The aims of the present work are (1) to describe a new Hogna species from Afghanistan, and (2) to redescribe two poorly known Hogna species from the Near East which remain known from the original descriptions.

\section{Material and Methods}

A total of 15 specimens studied have been borrowed from or deposited in the following museums: MMUE Manchester Museum, University of Manchester, Manchester, UK (curator: D.V. Logunov); OUNHM - Oxford University Natural History Museum, Oxford, UK (curator: Z. Simmons); SMFM - Naturmuseum und Forschungsinstitutt Senckenberg, Frankfurt am Main, Germany (curator: P. Jäger); ZMUM - Zoological Museum of the Moscow University, Moscow, Russia (curator: K.G. Mikhailov).

Digital photographs of the general appearance were made at the World Museum of Liverpool (UK) using a Canon 6D Mark II Camera with a Canon MP-E 65mm lens with Helicon Remote ver. 3.9.7W to control the StackShot $3 \mathrm{X}$ Macro Rail and camera settings. Distribution maps were produced by G.N. Azarkina (Novosibirsk, Russia) using the online mapping software SimpleMappr (Shorthouse, 2010).

The terminology and format of description follow Dondale \& Redner [1990] and Logunov [2010]; see also Figs 


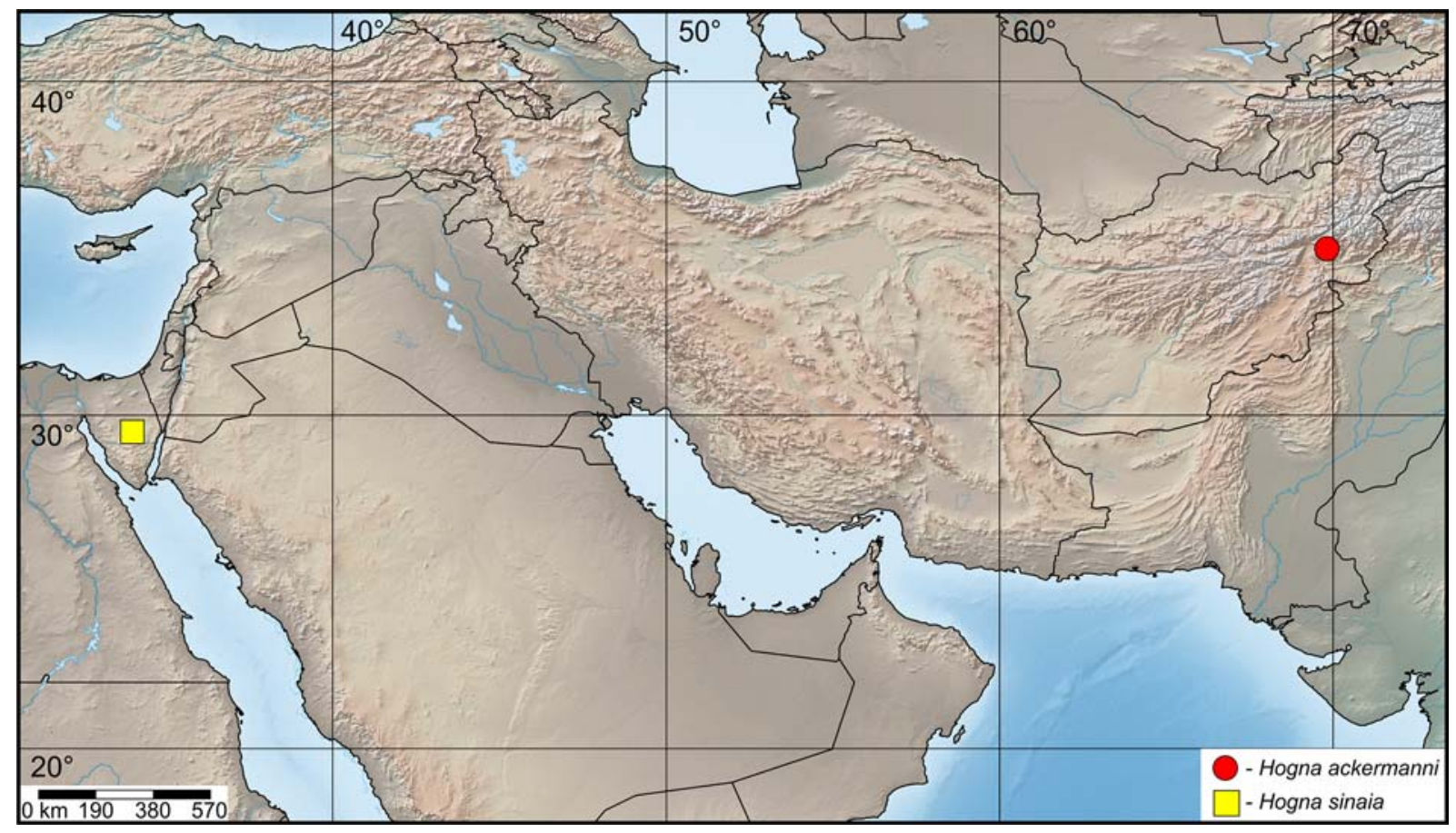

Map 1. Type localities of Hogna sinaia Roewer, 1959 (yellow square) and H. ackermanni sp.n. (red circle).

Карта 1. Типовые локалитеты Hogna sinaia Roewer, 1959 (желтый квадрат) и H. ackermanni sp.n. (красный кружок).

16, 17, 20-23. Abbreviations used in the text: AME anterior median eye, ALE - anterior lateral eye, Fm femur, Mt - metatarsus, PME - posterior median eye, $\mathrm{PLE}$ - posterior lateral eye, $\mathrm{Pt}$ - patella, $\mathrm{Tb}$ - tibia, $\mathrm{Tr}$ tarsus. The sequence of leg segments in measurement data is as follows: $\mathrm{Fm}+\mathrm{Pt}+\mathrm{Tb}+\mathrm{Mt}+\mathrm{Tr}$ (total). All measurements are in $\mathrm{mm}$.

\section{Description}

\section{Hogna ackermanni sp.n.}

Figs 1-18, 26, 27, Map 1.

TYPES. HоLотуре 9 (MMUE, G7642.1), Afghanistan, Kapisa Prov., Nijrab [c. $35^{\circ} 00^{\prime} \mathrm{N}, 69^{\circ} 49^{\prime} \mathrm{E}$ ], November 2012, W. Plu. The holotype female was collected alive and brought to Gordon Ackermann (Erlinsbach, Switzerland) who kept it in captivity; the female produced an egg cocoon from which both examined males originated. - PARATYPES: $1 \sigma^{7}$ (ZMMU), $1 \sigma^{7}$ (MMUE, G7642.2), captive bred, hatched from the cocoon produced by the holotype female in 20.03.2013, matured in August-September 2013, died and preserved in November 2013.

COMPARARIVE MATERIAL. Hogna radiata (Figs 19-21, 22, 23). FRANCE: $1 \Im^{7}, 2$ OP (MMUE, G7643.1), Gigouzac (F46), Le Salinié (c. $44^{\circ} 35^{\prime} 03.9^{\prime \prime} \mathrm{N}, 1^{\circ} 26^{\prime} 49.0^{\prime \prime} \mathrm{E}$ ), under mowings, 13.07.2017, S. Danflous.

ETYMOLOGY. The new species is dedicated to Gordon Ackermann (Erlinsbach, Switzerland), who successfully bred both sexes of this species in captivity and provided the author with the material to study.

DIAGNOSIS. Of the reliably illustrated Palaearctic $\mathrm{Ho}$ gna species (e.g., Wunderlich, 1992; Lecigne, 2016; Zonstein et al., 2015), the new species seems to be closest to $H$. radiata (Figs 19-21, 22, 23; see also figs 36-39 in Brady [2012]), from which it can be distinguished by the following characters: palea round in ventral view in $H$. ackermanni sp.n. (rectangular in $H$. radiata; cf. Figs 12 and 20); median apophysis in $H$. ackermanni sp.n. almost twice as narrow as that of $H$. radiata; cf. Figs 18 and 19, shown on the same scale); median apophysis without a white, membranous area at its base in $H$. ackermanni sp.n. (with a membranous area in $H$. radiata; cf. Figs 12 and 20); septal pedicel 1.5 times wider in $H$. ackermanni sp.n. than that of $H$. radiata; cf. Figs 26 and 22, shown on the same scale); posterior transverse plate of the septal pedicel in $H$. ackermanni sp.n. 1.3 times narrower than that of $H$. radiata; cf. Figs 26 and 22, shown on the same scale); proportions of median septum are different (pedicel width/septal base width ratio - 2.2 in $H$. ackermanni sp.n. and $4-4.2$ in $H$. radiata; cf. Figs 22, 26 and fig. 39 in Brady [2012]); primary/secondary receptacle length ratio -0.7 in $H$. ackermanni sp.n. and 1.4-1.6 in $H$. radiata (cf. Figs 27 and 23, and fig. 38 in Brady [2012]).

DISTRIBUTION. Only the type locality (Map 1).

DESCRIPTION. MALE (paratype from MMUE). Carapace 7.50 long, 5.15 wide. Eye sizes and inter-distances: AME 0.31, ALE 0.28, PME 0.63, PLE 0.50, AME-AME 0.15, AME-ALE 0.08, PME-PME 0.42, PLE-PLE 1.28. Width of anterior eye row 1.48 , second row 1.53 , third row 1.95. Clypeus height 0.25 , chelicera length 3.10. Abdomen 6.25 long, 3.50 wide. Length of leg segments: I $7.05+3.20$ $+5.70+6.50+3.60(26.05) ;$ II $6.60+2.90+5.10+6.25+$ 3.55 (24.40); III $5.80+2.50+4.20+6.05+3.34$ (21.90); IV $7.30+2.90+6.05+8.80+4.05$ (29.10). Leg formula: IV,I,II,III. Coloration (Figs 5-7, 10, 11). Carapace yellowish brown, densely covered with brownish and yellowish white recumbent hairs; AMEs surrounded by white and orange-coloured hairs. Clypeus yellowish brown. Chelicerae brown, anteriorly two thirds of their length densely covered with yellowish white recumbent hairs (Fig. 5). Sternum and coxae brown, densely covered with black recumbent hairs. 


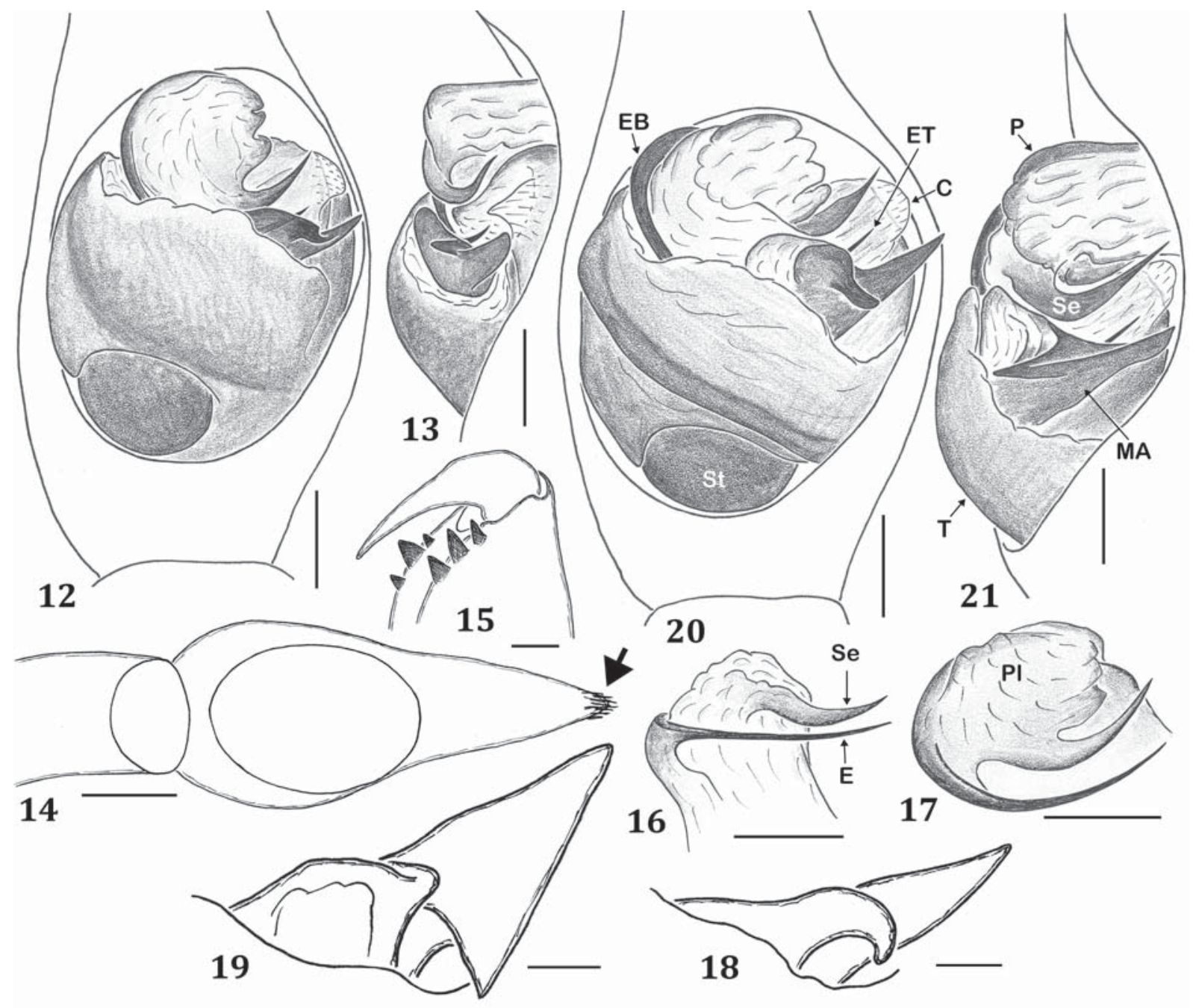

Figs 12-21. Male copulatory organs and somatic morphology of Hogna ackermanni sp.n. (12-14, 16-18, paratype $0^{7}$ from MMUE, 15, holotype + ) and $H$. radiata (Latreille, 1817) (19-21, from France): 12, 20 - left male palp, ventral view; 13, 21 - ditto, retrolateral view; 14 - cymbium, ventral view; 15 - left female chelicera, ventral view; 16 - embolar division, ventral view; 17 - ditto, apical view; $18,19-$ median apophysis, apical view. Scale bars: $0.1 \mathrm{~mm}(18,19), 0.25 \mathrm{~mm}(12,13,16,17,20,21), 0.5 \mathrm{~mm}(14,15)$. Abbreviations: C - conductor, E - embolus, EB — embolic base, ET - embolic tip, MA — median apophysis, P — palea, St subtegulum, $\mathrm{T}$ - tegulum

Рис. 12-21. Копулятивные органы самцов и соматическая морфология Hogna ackermanni sp.n. (12-14, 16-18, паратип О7 из MMUE, 15, голотип +) и H. radiata (Latreille, 1817) (19-21, из Франции): 12, 20 - левая пальпа самца, вид снизу; 13, 21 - то же, вид сбоку-сзади; 14 - цимбиум, вид снизу; 15 - левая хелицера самки, вид снизу; 16 - эмболярный отдел, вид снизу; 17 - то же, вид сверху; 18, 19 - медиальный апофиз, вид сверху. Масштаб: 0,1 мм $(18,19), 0,25$ мм $(12,13,16,17,20,21), 0,5$ мм $(14,15)$. Сокращения: С — кондуктор, Е - эмболюс, ЕВ - основание эмболюса, ЕТ — вершина эмболюса, МА - медиальный апофиз, Р палеа, $\mathrm{St}$ - субтегулум, T - тегулум.

Labium dark brown, endites yellowish brown (Fig. 7). Abdomen: dorsum densely covered with yellowish white recumbent hairs, with a poorly marked brown colour pattern of a pale cardiac mark and two pairs of brown spots; sides light yellow; venter (including book-lung covers) light yellow densely covered with black recumbent hairs and with two white spots at the lateral ends of the epigastric furrow (Fig. 7). Spinnerets light yellow, covered with brownish and white hairs. All legs orange-yellow, densely covered with yellowish white recumbent hairs; tibiae ventrally-apically brownish. Palps yellow, with brownish cymbium and brown bulb. Palpal structure as in Figs 12-14, 16-18: cymbium elongated, 2.2 times longer than wide, with a bunch of apical macrosetae; subtegulum prominent, situated proxi- mally, at 7 o'clock; palea round; synembolus sickle-shaped, as long as palea width; median apophysis narrow, with a pointed retrolateral end and a prominent ventral tooth; embolus twice as long as synembolus.

FEMALE (holotype). Measurements. Carapace 8.90 long, 7.00 wide. Eye sizes and inter-distances: AME 0.38, ALE 0.35, PME 0.73, PLE 0.65, AME-AME 0.16, AME-ALE 0.10 , PME-PME 0.53, PLE-PLE 1.80. Width of anterior eye row 1.83, second row 2.00, third row 2.60. Clypeus height 0.33 , chelicera length 4.50 . Abdomen 10.00 long, 6.90 wide. Length of leg segments: I $7.25+3.50+5.25+5.10+2.80$ (23.90); II $6.75+3.00+4.65+4.90+2.90$ (22.20); III 6.00 $+2.50+3.75+4.90+2.75(19.90) ;$ IV $8.00+3.40+5.75+$ $7.15+3.30$ (27.60). Leg formula: IV,I,II,III. Coloration 


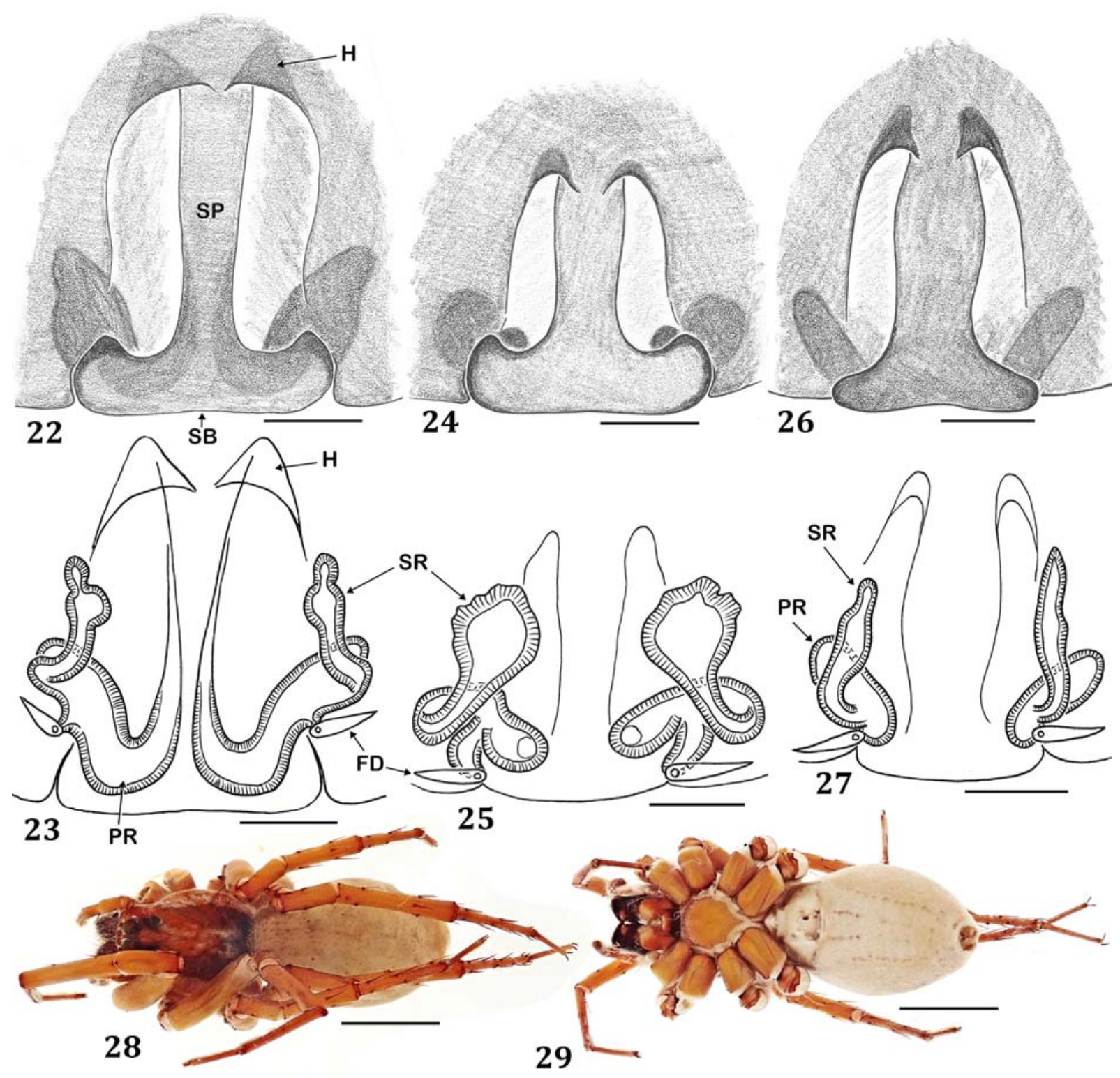

Figs 22-29. Female copulatory organs and somatic morphology of Hogna radiata (Latreille, 1817) (19-21, from France), H. sinaia Roewer, 1959 (24, 25, 28, 29, holotype + ) and H. ackermanni sp.n. (26, 27, holotype + ): 22, 24, 26 - epigyne, ventral view; 23, 25, $27-$ vulva, dorsal view; 28 - body, dorsal view; 29 - ditto, ventral view. Scale bars: $0.25 \mathrm{~mm}(22-27), 0.5 \mathrm{~mm}(28,29)$. Abbreviations: FD fertilization duct, $\mathrm{H}$ - hood, PR — primary receptacle, SB — septal base, SR — secondary receptacle, SP — septal pedicel.

Рис. 22-29. Копулятивные органы самок и соматическая морфология Hogna radiata (Latreille, 1817) (19-21, из Франции), H. sinaia Roewer, 1959 (24, 25, 28, 29, голотип +) и H. ackermanni sp.n. (26, 27, голотип +): 22, 24, 26 - эпигина, вид снизу; 23, 25, 27 вульва, вид сверху; 28 - тело, вид сверху; 29 - то же, вид снизу. Масштаб: 0,25 мм (22-27), 0,5 мм (28, 29). Сокращения: FD оплодотворительный каналец, H - карман, PR - первичный семеприёмник, SB - основание септума, SR — вторичный семеприёмник, SP - ножка септума.

(Figs 1-4, 8, 9, 11). Carapace brown, densely covered with yellowish white recumbent hairs. Clypeus brown, covered with yellowish white hairs; AMEs surrounded by white and orange-coloured hairs. Chelicerae brown, anteriorly two thirds of their length densely covered with yellowish white recumbent hairs (Fig. 4). Sternum and coxae brown, densely covered with black recumbent hairs. Labium and endites dark brown (Fig. 3). Abdomen: dorsum and sides brown, densely covered with yellowish white recumbent hairs, with no colour pattern; venter (including book-lung covers) brown, densely covered with black recumbent hairs. Spinnerets brown, covered with brownish hairs. All legs brown, densely covered with yellowish white recumbent hairs; tibiae, metatarsi and tarsi of legs I-III ventrally dark brown. Palps brown, densely covered with yellowish white recumbent hairs. Epigyne and vulva as in Figs 26, 27: median septum longer than wide (septal length/wide ratio 1.2); hoods separated by one hood width; secondary receptacles tube-shaped, as wide as insemination ducts; fertilization ducts prominent, situated near epigastric furrow. 


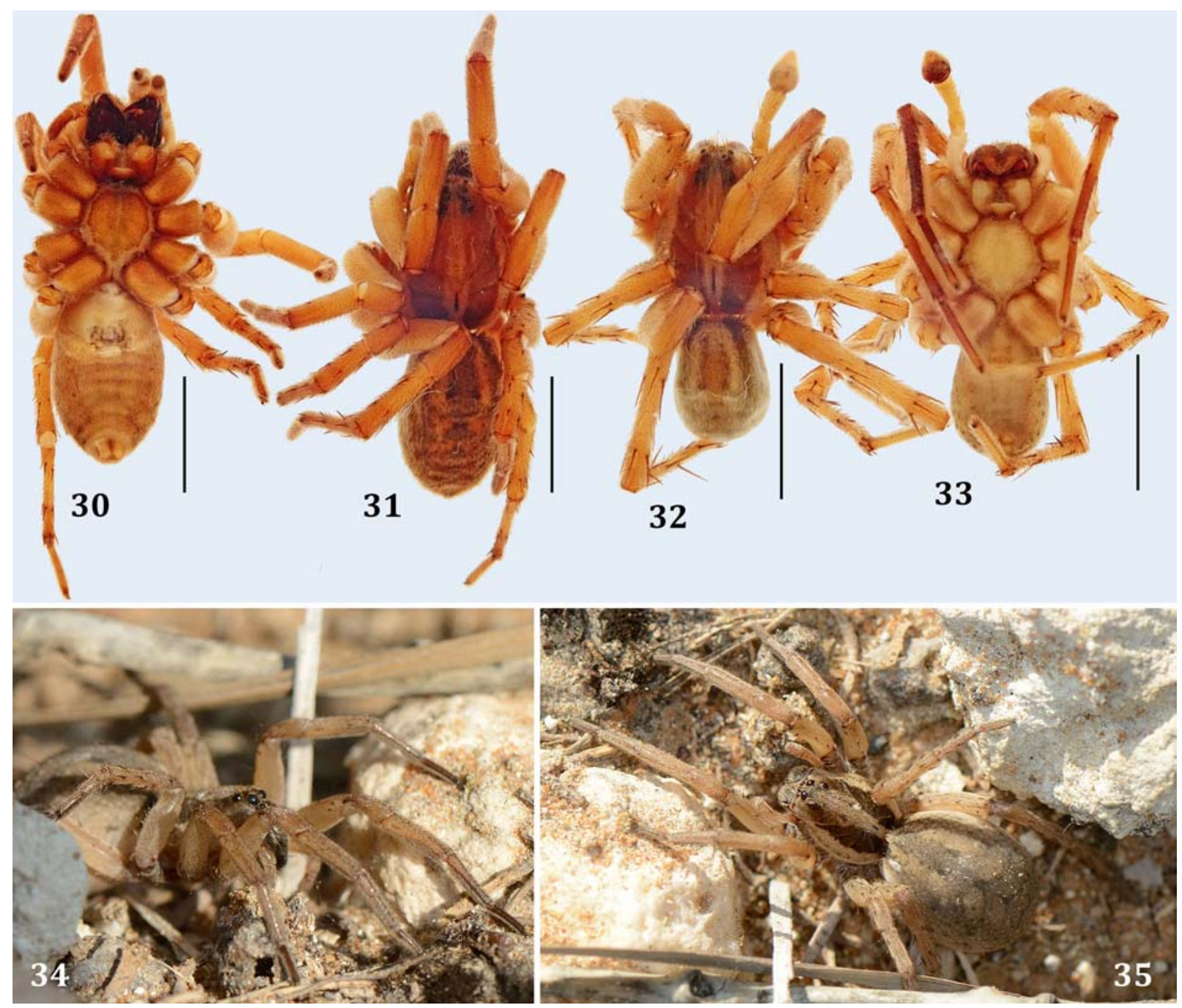

Figs 30-35. General appearance of Hogna effera (O. Pickard-Cambridge, 1872) (30, 31, paralectotype $9,32,33$, lectotype $0^{7}, 34,35$, from the UAE): 30, 33 - body, ventral view; 31, 32 - ditto, dorsal view; 34, 35 - live female. Photos 34, 35, credits to Huw Roberts (Abu Dhabi, the UAE). Scale bars: $5 \mathrm{~mm}$.

Рис. 30-35. Общий вид Hogna effera (O. Pickard-Cambridge, 1872) (30, 31, паралектотип $9,32,33$, лектотип $0^{7}, 34,35$, из ОАЭ): 30, 33 - тело, вид снизу; 31, 32 - то же, вид сверху; 34, 35 - живая самка. Фотографии 34, 35, признательность Хью Робертс (Абу-Даби, ОАЭ). Масштаб: 5 мм.

Hogna effera (O. Pickard-Cambridge, 1872), comb.n. Figs 30-43, Map 2.

Lycosa effera O. Pickard-Cambridge, 1872: 318 (D $0^{7}+$ ); $0^{7}$ lectotype designated here, in OUNHM.

Hyaenosa effera: Roewer, 1955a: 260; 1960a: 821, figs 455a-

c (O'P); Zonstein, Marusik, 2013: 59.

Trochosa effera: O. Pickard-Cambridge, 1876: 601.

Tarentula iaffa Strand, 1913: 161 (D); ; holotype 9 from SMFM, 2232-138, not examined, but see Zonstein et al. [2015: fig. 2h] Syn.n.

Geolycosa altera Roewer, 1955b: 764, fig. 12 (D+); holotype $\circ$ from SMFM, examined (see Logunov [2012]. Syn.n.

Trochosa altera: Logunov, 2012: 355, figs 20-21 (To from Geolycosa).

Geolycosa iaffa: Roewer, 1955a: 241; Zonstein, Marusik, 2013: 59.

Lycosa ferox: Denis, 1947: 32, pl. 1, figs 3-5 ( $0^{7}$ \% $)$.

Lycorma ferox: Alderweireldt, van Harten, 2004: 352

Hogna ferox: Zonstein et al., 2015: 377, fig. 2h,i (+); Lecigne,
2016: 99, figs 7, L-O $\left(\mathrm{O}^{7}\right)$; Alderweireldt, Jocqué, 2017: 5; Bosmans et al., 2019: 86.

TYPES. LeCtotype $O^{7}$ (designated here; Figs 32, 33, 36-38) (OUNHM, bottle 1572, tube 41), 'no exact locality and date'; in the original description [Pickard-Cambridge, 1872: 319], the type locality was not properly defined, stating that "examples of both sexes, adult and immature, were found at Jericho, Hebron, the Lebanon and Beirut". Paralectotypes: 1 + (OUNHM, bottle 1572, tube 41), together with the lectotype; 4 immatures (OUNHM, bottle 1572 , tube 14), 'no exact locality and date'.

The adult syntype 9 of Lycosa effera from Syria deposited in SMFM (no. 9910928) has been re-examined and turned out to belong to the genus Arctosa. The taxonomic assignment of an immature female of Hyaenosa effera from SMFM (no. 9913477), which was also re-examined by the author, remains unclear, but it seems to belong to Alopecosa Simon, 1885 .

OTHER MATERIAL. UAE: 1 ( (MMUE; Figs 34, 35, 42, 43), Jebel Hafeet Mercure Hotel $\left(24^{\circ} 04^{\prime} 40.8^{\prime \prime} \mathrm{N}, 55^{\circ} 46^{\prime} 08.4^{\prime \prime} \mathrm{E}\right), 14.01$. 2014, H. Roberts; 1 ㅇ (MMUE), same locality, 20.08.2016, H. Roberts. - IRAN: 1 (MMUE), Mazandaran (no exact locality), oak forest, 06.2004, H. Ghahari; $1 \sigma^{7}$ (MMUE), Isfahan, Najaf- 


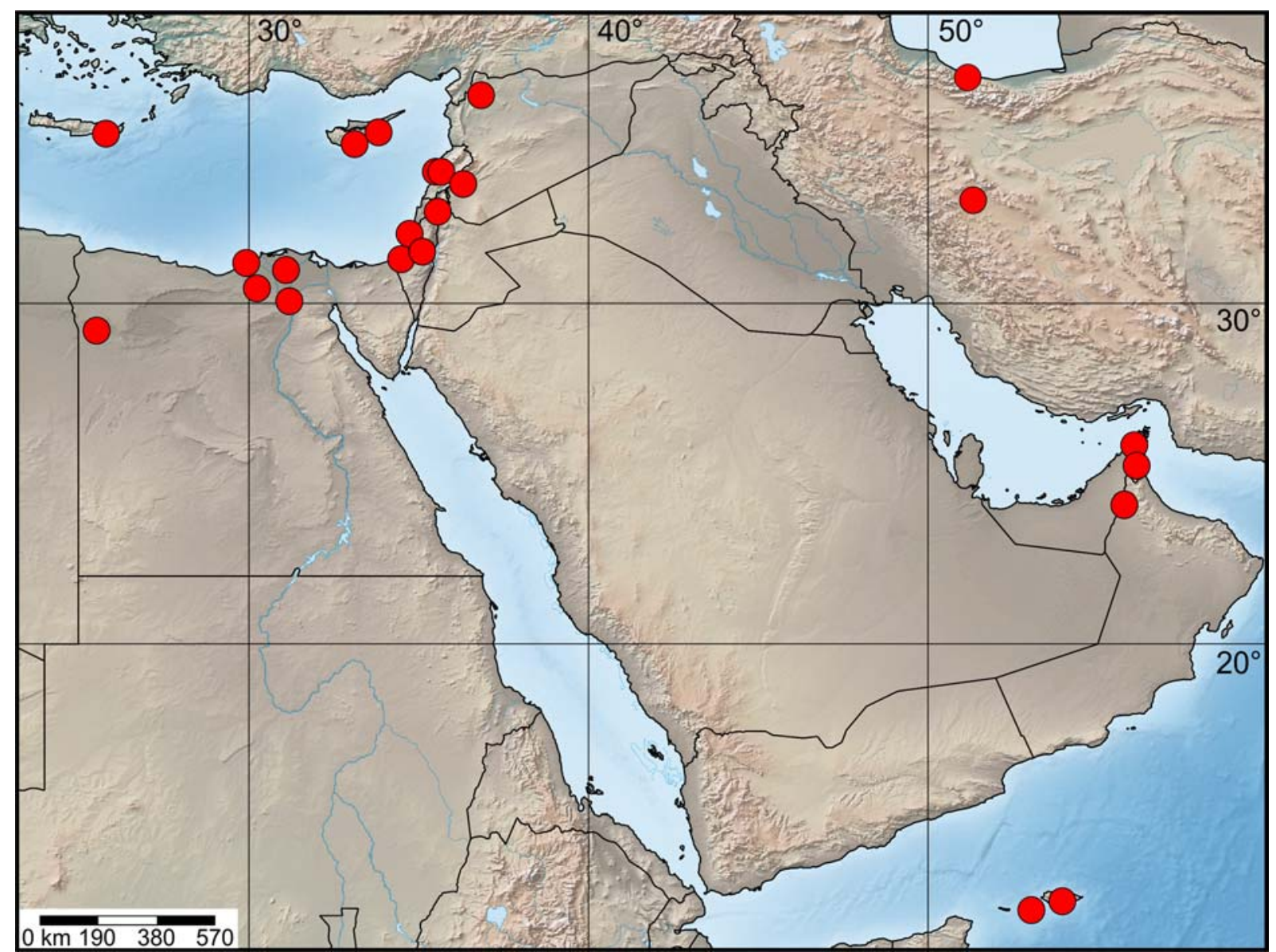

Map 2. Collecting localities of Hogna effera (O. Pickard-Cambridge, 1872).

Карта 2. Точки находок Hogna effera (O. Pickard-Cambridge, 1872).

Abad (c. $32^{\circ} 39^{\prime} \mathrm{N}, 51^{\circ} 22^{\prime} \mathrm{E}$ ), almond orchards, 09.2000, H. Ghahari.

COMPARATIVE MATERIAL. Hogna ferox (Lucas, 1838) (Figs 44, 45). SPAIN: 1 (MMUE, G7572.18234), The Canary Islands, Gran Canaria, Juan Grande [c. $27^{\circ} 49^{\prime} \mathrm{N}, 15^{\circ} 28^{\prime} \mathrm{W}$ ], 27.03. 1997, J. Murphy.

DIAGNOSIS. Hogna effera seems to be closest to $H$. ferox, which was described from and is reliably know only from the Canaries [Wunderlich, 1992; Hepner \& Paulus, 2009]; see also below under 'Distribution'. Based on the available schematic illustrations of specimens of H. ferox (viz., figs 716-719 in Wunderlich [1992] and figs 14-16 in Hepner \& Paulus [2009]) and the female from Gran Canaria re-examined by the author (Figs 44, 45), H. effera can be readily distinguished from $H$. ferox by the following characters: the base of median apophysis in the male palp of $H$. effera is about twice as narrow as that of H. ferox (if measured in the apico-proximal direction; cf. Fig. 36 with fig. 717 in Wunderlich [1992]); the septal pedicel is visibly constricted in its posterior half in $H$. effera (not constricted, with subparallel edges in $H$. ferox; cf. Figs 39, 42 and 44; see also fig. 719 in Wunderlich [1992] and fig. 15 in Hepner \& Paulus [2009]); hoods separated by $1-1.5$ hood diameter in H. effera (touching in H. ferox; cf. Figs 39, 42 and 44); and the vulva of $H$. effera is comparatively smaller than that of $H$. ferox (septal pedicel length/vulva height ratio: 1.5-1.6 in H. effera, and 1.00 in H. ferox; cf. Figs 40, 43 and 45, illustrated on the same scale; see also fig. 16 in Hepner \& Paulus [2009]).

COMMENTS. Lycosa effera was transferred to the genus Hyaenosa Caporiacco, 1940 by Roewer [1955a: 260] without any justification; followed by WSC [2020]. However, Hyaenosa was described by Caporiacco [1940] as a monotypic genus based on an immature female $-H$. strandi Caporiacco, 1940 from Ethiopia - and, in my opinion, the taxonomic status and validity of both the genus Hyaenosa and its type species requires revision. L. effera conforms to all the diagnostic characters of the genus Hogna listed above in 'Introduction' and hence it is safe to propose a new combination: Hogna effera (O. Pickard-Cambridge, 1872), comb.n. (ex Hyaenosa).

Zonstein et al. [2015] synonymized the name of Tarentula iaffa Strand, 1913 with $H$. ferox by comparison of the holotype female from Tel-Aviv with newly collected specimens from Israel. However, as it is clear now that all the records of $H$. ferox from Israel are to be re-assigned to $H$. effera, and therefore T. iaffa is to be considered a junior synonym of $H$. effera. Geolycosa altera Roewer, 1955 was described by Roewer [1955a] on the basis of the holotype female from Iran. The holotype of this species was illustrated by Logunov [2012: figs 20-21] who also mistakenly transferred this species name to Trochosa C.L. Koch, 1847. Based on the results of the present study, the latter species has copulatory organs that closely resemble those of $H$. 


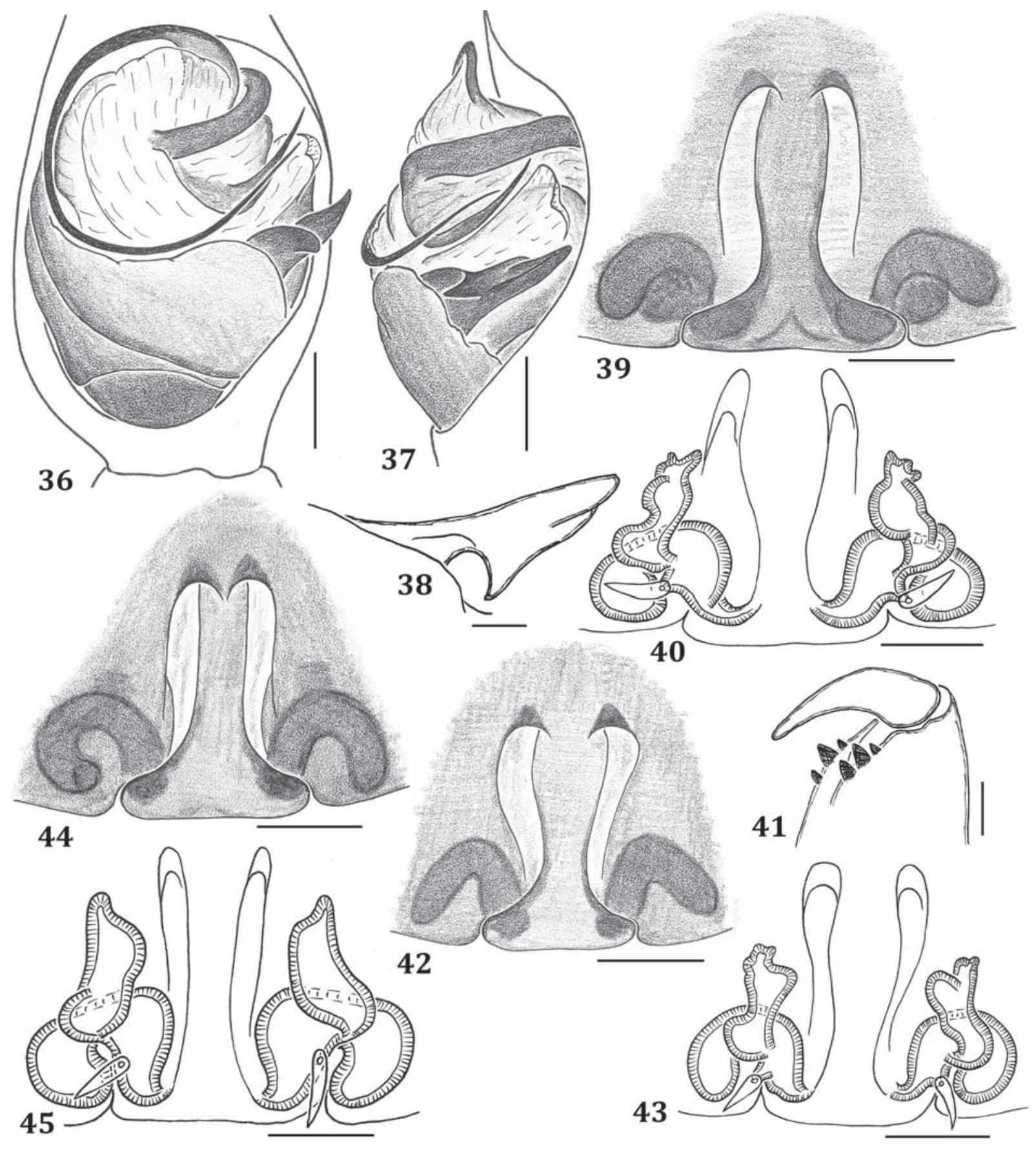

Figs 36-45. Copulatory organs and somatic morphology of Hogna effera (O. Pickard-Cambridge, 1872) (36-38, lectotype $0^{7}$, 39-41, paralectotype $+, 42,43$, from the UAE) and $H$. ferox (Lucas, 1838) (44, 45, from the Canary Islands): 36 - left male palp, ventral view; 37 ditto, retrolateral view; 38 - median apophysis, apical view; 39, 42, 44 - epigyne, ventral view; 40, 43, 45 - vulva, dorsal view; 41 left female chelicera, ventral view. Scale bars: $0.1 \mathrm{~mm}(38), 0.25 \mathrm{~mm}(36,36,39-40,42-45), 0.5 \mathrm{~mm}(41)$.

Рис. 36-45. Копулятивные органы и соматическая морфология Hogna effera (О. Pickard-Cambridge, 1872) (36-38, лектотип О', 39-41, паралектотип + , 42, 43, из ОАЭ) и H. ferox (Lucas, 1838) (44, 45, из Гран-Канария): 36 — левая пальпа самца, вид снизу; 37 то же, вид сзади-сбоку; 38 - медиальный апофиз, виз сверху; 39, 42, 44 - эпигина, вид снизу; 40, 43, 45 — вульва, вид сверху; 41 левая хелицера самки, вид снизу. Масштаб: 0,1 мм (38), 0,25 мм (36, 36, 39-40, 42-45), 0,5 мм (41).

effera (Figs 39, 40, 42, 43) and therefore is to be considered its junior synonym.

DISTRIBUTION. Although the distribution of $H$. effera cannot be reliably outlined at present, the species seems to occur at least in the eastern Mediterranean, the Near East and Saudi Arabia (Map 2), whence it has been recorded under different names, most commonly as Hogna ferox: viz., Crete [Lecigne, 2016: sub Hogna ferox], Cyprus [Bosmans et al., 2019: sub Hogna ferox], Egypt [Pickard-Cambridge, 1876: sub Trochosa effera; Denis, 1947: sub Lycosa ferox; 
Roewer, 1960a: sub Hyaenosa e.; El-Hennawy, 2017: sub Hogna ferox \& Hyaenosa e.], Lebanon [Pickard-Cambridge, 1872; Roewer, 1960a: sub Hyaenosa e.], Israel [PickardCambridge, 1872; Strand, 1913: sub Tarentula iaffa; Zonstein, Marusik, 2013: sub Hyaenosa e.; Zonstein et al., 2015: sub Tarentula iaffa \& Hogna ferox], Syria [Denis, 1947: sub Lycosa ferox], Iran [Roewer, 1955b: sub Geolycosa altera; Logunov, 2012: sub Trochosa altera; present data], Yemen, Saudi Arabia [Alderweireldt, van Harten, 2004: sub Lycorma ferox] and the UAE [Alderweireldt, Jocqué, 2017: sub Hogna ferox; present data].

Apparently, some records of Hogna radiata from Greece (see Bosmans \& Chatzaki, 2005; Bosmans et al., 2013) are likely to belong to $H$. effera as well. The record by Roewer [1960a: fig. 455a, sub Hyaenosa e.] from Libya (Derna) based on a single female actually belong to a different species and even genus of Lycosidae.

As stated in the original description [Lucas, 1838: 27], Lycosa ferox was collected from the Canary Islands (trouvé aux îles Canaries), but the type locality was not specified. According to Arechavaleta et al. [2010], the species is known from the seven islands of the archipelago. Yet, earlier, Wunderlich [1992: 459] argued that Lucas' [1838] description could refer to several Hogna species and does not allow a reliable interpretation, whereas the whereabouts of the original type series of L. ferox remains unknown. Hence, Wunderlich [1992] nominated the largest Canarian Hogna species of the six known from there as the true H. ferox, and this notion is followed here. Later, H. ferox was also illustrated by Hepner \& Paulus [2009] based on the specimens from Gran Canaria, being conspecific with the species illustrated by Wunderlich [1992]. Guy [1966: figs 56a-c] presented three variations of the epigyne of $H$. ferox, which unfortunately cannot be taken into consideration because they were not geographically specified and include both what could be interpreted as H. ferox (sensu Wunderlich [1992]; see also Fig. 44), with an unconstricted septal pedicel [Ibid.: fig. 56a], and $H$. effera, with a constricted pedicel [Ibid.: fig. 56b]. Indeed, Guy [1966: 113] considered both names as belonging to one species.

Based on the diagnosis given above and the fact that the type locality of H. ferox lies in the Canaries, the current idea of the species being a widespread Mediterranean species [Guy, 1966; Zonstein et al., 2015; Nentwig et al., 2020; WSC, 2020] needs verification. At least, most of the reliably illustrated records of $H$. ferox from the eastern Mediterranean (e.g., Denis, 1947; Zonstein et al., 2015; Lecigne, 2016; etc.) and Saudi Arabia (Figs 42, 43) appear to belong to $H$. effera.

DESCRIPTION. MALE (lectotype). Carapace 5.90 long, 3.90 wide. Eye sizes and interdistances: AME 0.25, ALE 0.18 , PME 0.45 , PLE 0.40, AME-AME 0.08, AME-ALE 0.08 , PME-PME 0.23, PLE-PLE 0.70 . Width of anterior eye row 1.00 , second row 1.00 , third row 1.38 . Clypeus height 0.15 , chelicera length 2.26. Abdomen 4.40 long, 2.90 wide. Length of leg segments: I $4.80+2.25+4.10+4.15+2.40$ (17.70); II $4.50+2.00+3.50+3.55+2.25(15.80) ;$ III $4.10+$ $1.80+2.90+3.80+2.15(14.75) ;$ IV $5.50+2.10+4.20+$ $6.00+2.80(20.60)$. Leg formula: IV,I,II,III. Coloration (Figs 32, 33); the specimen is visibly faded. Carapace light yellow, with a pattern made of dense recumbent hairs: two wide longitudinal brown stripes, a wide white stripe in between them and two wide white marginal bands; brown fovea prominent and long (Fig. 32). Clypeus light yellow. Sternum light yellow, densely covered with white hairs.
Labium and endites light yellow. Chelicerae yellowish brown. Abdomen: dorsum yellow-grey, with a yellow cardiac mark edged with brown lines; sides yellow-grey; venter light yellow. Book-lung covers and spinnerets light yellow. All legs light yellow, but Mt and Tr I-II orange-brown. Palps light yellow, with brownish bulbs. Palpal structure as in Figs 3638: cymbium elongated; subtegulum prominent, situated proximally, at 6 o'clock; palea round; synembolus needleshaped; median apophysis narrow-triangular (in apical view), with a pointed retrolateral end and a low ventral tooth; embolus six times longer than synembolus, originating at 12 o'clock and clearly visible along all its length.

FEMALE (paralectotype). Carapace 6.25 long, 5.05 wide. Eye sizes and inter-distances: AME 0.28, ALE 0.16, PME 0.43 , PLE 0.45, AME-AME 0.16, AME-ALE 0.10, PMEPME 0.38, PLE-PLE 1.00. Width of anterior eye row 1.33, second row 1.30, third row 1.63. Clypeus height 0.15 , chelicera length 3.10. Abdomen 7.10 long, 3.85 wide. Length of leg segments: I $4.85+2.50+3.10+3.20+2.05(15.70)$; II $4.20+2.30+2.85+3.05+2.00(14.40)$; III $3.85+2.05+$ $2.50+3.50+2.00(13.90) ;$ IV $4.25+1.95+3.35+4.35+$ 2.10 (16.00). Leg formula: IV,I,II,III. Coloration (Figs 30, $31,34,35)$, as in the male, except for yellowish brown labium and endites, dark brown chelicerae, and a better visible, brownish colour pattern of dorsum (Figs 31, 35). Epigyne and vulva as in Figs 39, 40, 42, 43: median septum longer than wide (septal length/width ratio 1.1-1.5); hoods separated by $1-1.5$ hood diameter; secondary receptacles as wide as insemination ducts; fertilization ducts prominent, situated near epigastric furrow.

\section{Hogna sinaia Roewer, 1959 Figs 24, 25, 28, 29, Map 1.}

Hogna sinaia Roewer, 1959: 412, figs 222a,b ( $\mathrm{D}_{+}^{\circ}$ ); holotype + in SMFM, examined.

TYPES. НоLотуре $q$ (SMFM, 11752; Figs 24, 25, 28, 29), "Aran.: Lycosidae No. 792 / Hogna sinaia n.sp. Rwr. / 19, 1(Oinad.) / Sinai-Halbi[...further illegible] / Rwr. Det. 1957"; apparently, Sinai-Halbinsel (Nuweiba, Egypt; c. $\left.29^{\circ} 30^{\prime} \mathrm{N}, 34^{\circ} 00^{\prime} \mathrm{E}\right)$. The type series contains two specimens, of which one is an immature female, but these cannot be treated as the syntypes because in the original description Roewer [1959: 412-413] designated the mature female as the holotype and then illustrated and described it.

DIAGNOSIS. Of the reliably illustrated females of Palaearctic Hogna species, $H$. sinaia is most similar to that of $H$. radiata (Figs 22, 23) in having the anchor-shaped median septum (Fig. 24). It differs from the latter species in the shorter (1.4 times) septal pedicel (cf. Figs 24 and 22, shown on the same scale) and the unique, globular secondary receptacles (tubular in $H$. radiata and all other Hogna species illustrated to date; cf. Figs 25 and 23). The male of $H$. sinaia remains unknown.

DISTRIBUTION. Only the type locality (Map 1).

DESCRIPTION. MALE unknown.

FEMALE (holotype). Carapace 6.80 long, 5.50 wide. Eye sizes and inter-distances: AME 0.33, ALE 0.28, PME 0.78, PLE 0.68, AME-AME 0.13, AME-ALE 0.13, PMEPME 0.38, PLE-PLE 1.30. Width of anterior eye row 1.50, second row 1.80, third row 2.25. Clypeus height 0.25 , chelicera length 3.15. Abdomen 9.80 long, 6.50 wide. Length of leg segments: I $5.80+2.00+4.60+4.55+2.70(19.65)$; II $5.40+2.70+3.85+4.15+2.35(18.45) ;$ III $4.80+2.45+$ $3.70+4.50+2.50(17.95) ;$ IV $6.40+2.95+5.35+7.95+$ 3.10 (25.75). Leg formula: IV,I,II,III. Coloration (Figs 28, $29)$; the specimen is markedly faded and shabby, with the 
Table. Hogna species in some regional faunas of Asia Minor and the Near East. Таблица. Виды Hogna в некоторых региональных фаунах Малой Азии и Ближнего Востока.

\begin{tabular}{|c|c|c|c|c|c|}
\hline \multirow[t]{2}{*}{ Species } & \multicolumn{5}{|c|}{ Regions/Countries } \\
\hline & Caucasus & Egypt & Iran & Israel & Turkey \\
\hline H. alexandria Roewer, 1960 & & $\mathrm{X}$ & & & \\
\hline H. bergsoei (Thorell, 1875) & $\mathrm{X}$ & & & & \\
\hline H. effera (O. P.-Cambridge, 1872) & & $\mathrm{X}$ & $\mathrm{X}$ & $\mathrm{X}$ & \\
\hline H. felina (L. Koch, 1878) & $\mathrm{X}$ & & & & \\
\hline H. graeca (Roewer, 1951) & & & & & $\mathrm{X}$ \\
\hline H. nigrichelis (Roewer, 1955) & & & $\mathrm{X}$ & & \\
\hline H. ocellata (L. Koch, 1878) & $\mathrm{X}$ & & & & \\
\hline H. peregrina (Audouin, 1826) & & $\mathrm{X}$ & & & \\
\hline H. radiata (Latreille, 1817) & $\mathrm{X}$ & $\mathrm{X}$ & $\mathrm{X}$ & $\mathrm{X}$ & $\mathrm{X}$ \\
\hline H. sinaia Roewer, 1959 & & $\mathrm{X}$ & & & \\
\hline $\begin{array}{l}\text { H. truculenta (O. P.-Cambridge, } \\
\text { 1876) }\end{array}$ & & $\mathrm{X}$ & & & \\
\hline Total number & 4 & 6 & 3 & 2 & 2 \\
\hline
\end{tabular}

Based on the following sources: the Caucasus [Otto, 2020], Egypt [El-Hennawy, 2017], Iran [Zamani et al., 2020], Israel [Zonstein, Marusik, 2013; Zonstein et al., 2015], Turkey [Demir, Seyyar, 2017]; in all cases with modifications based on the results of the present study and Logunov \& Ponomarev [2020].

right leg I detached. Carapace yellow, with two wide brown longitudinal stripes of recumbent hairs and three longitudinal white stripes (a median and two marginal) of recumbent hairs. Clypeus yellow. Sternum light yellow. Labium and endites yellowish brown. Abdomen light yellow, with a pale cardiac mark on dorsum. Book-lung covers and spinnerets yellow. All legs and palps yellow. Epigyne and vulva as in Figs 24, 25: median septum as long as wide (septal length/ wide ratio 1.0); hoods separated by one hood width; secondary receptacles swollen and globular, more than twice the width of insemination ducts; fertilization ducts prominent, situated near epigastric furrow.

\section{Discussion}

As already mentioned in the introduction, the taxonomy and world diversity of the genus Hogna are confusing. Even its regional diversity remains poorly understood. The Table presents a list of 11 Hogna species described or recorded from five reasonably well studied regional faunas of the Caucasus, Asia Minor and the Near East. Of these, only two species have been reported from several regions: viz., H. radiata from all the five regions and $H$. effera from three regions. Yet, the extended distribution of the latter species is based on the revised data from the present study (see above), whereas the records of $H$. radiata are likely to have been based, at least partly, on misidentifications. The current state of knowledge of the supposedly common $H$. radiata requires a re-examination of its type series, if it exists, or a designation of a neotype to fix this name to a particular morphotype of those that are currently assigned to it (e.g., Brady [2012]).
All other Hogna species described from the area at hand (Table) remain known from old, poorly illustrated original descriptions (e.g., H. felina from eastern Georgia, H. nigrichelis from Iran, etc.) and are likely to be either nomina dubia (e.g., $H$. peregrina from Egypt; see Alderweireldt [1991]) or require revision (e.g., H. bergsoei from the eastern Caucasus; see Logunov \& Ponomarev [2020]). One species - H. truculenta from Egypt - was described based on an immature female [Pickard-Cambridge, 1876: 601-602]. The author commented that the species "is very nearly allied in colours and general appearance" to $H$. effera. Either this species name is to be treated as nomen dubium, or it is another record of the latter species; in both cases the name is not valid. All these problems lie outside the scope of the present study and are to be properly dealt with elsewhere.

Acknowledgements. I am most grateful to the following colleagues who helped me during preparation of the present work: Gordon Ackermann (Erlinsbach, Switzerland) for giving an opportunity to study specimens of the new species and for allowing me to use some of his photos of live specimens (Figs 5, 8-11); Zoë Simmons (OUNHM) and Peter Jäger (SMFM) for giving access to the spider collections of their museums; Galina N. Azarkina (Novosibirsk, Russia) for producing the maps; Tony Hunter (Liverpool, UK) for allowing me to use the digital facilities at the World Museums of Liverpool (UK); Phillip Rispin (Manchester, UK) for making some digital photos (Figs 28-33); Huw Roberts (Abu Dhabi, United Arab Emirates) for giving access to his spider collection from the UAE and allowing me to use photos of live specimens of $H$. effera (Figs 34, 35); and Anthony Russell-Smith (Kent, UK) for commenting on the ms and kind linguistic help. 


\section{References}

Alderweireldt M. 1991. A revision of the African representatives of the wolf spider genus Evippa Simon, 1882 (Araneae, Lycosidae) with notes on allied species and genera // Journal of Natural History. Vol.25. No.2. P.359-381. doi:10.1080/ 00222939100770261

Alderweireldt M., Jocqué R. 2017. Order Araneae, family Lycosidae // Arthropod fauna of the UAE. Vol.6. P.3-20.

Alderweireldt M., van Harten A. 2004. A preliminary study of the wolf spiders (Araneae: Lycosidae) of the Socotra Archipelago // Fauna of Arabia. Vol.20. P.349-356.

Almquist S. 2005. Swedish Araneae, part 1 - families Atypidae to Hahniidae (Linyphiidae excluded) // Insect Systematics \& Evolution. Supplement 62. P.1-284.

Arechavaleta M., Rodríguez S., Zurita N., García A. (eds.). 2010. Lista de especies silvestres de Canarias. Hongos, plantas y animales terrestres. 2009. Santa Cruz de Tenerife: Gobierno de Canarias, $577 \mathrm{pp}$.

Bosmans R., Chatzaki M. 2005. A catalogue of the spiders of Greece - a critical review of all spider species cited from Greece with their localities // Nieuwsbrief van de Belgische Arachnologische Vereniging. Vol.20. No.2 (Supplement). P.1124.

Bosmans R., Van Keer J., Russell-Smith A., Kronestedt T., Alderweireldt M., Bosselaers J., De Koninck H. 2013. Spiders of Crete (Araneae). A catalogue of all currently known species from the Greek island of Crete // Nieuwsbrief van de Belgische Arachnologische Vereniging. Vol.28. Suppl.1. P.1-147.

Bosmans R., Van Keer J., Russell-Smith A., Hadjiconstantis M., Komnenov M., Bosselaers J., Huber S., McCowan D., Snazel R., Decae A., Zoumides C., Kielhorn K.-H., Oger P. 2019. Spiders of Cyprus (Araneae). A catalogue of all currently known species from Cyprus // Newsletter of the Belgian arachnological Society. Vol.34 (Supplement). P.1-173.

Brady A.R. 2012. Nearctic species of the new genus Tigrosa (Araneae: Lycosidae) // Journal of Arachnology. Vol.40. No.2. P.182-208.

Caporiacco di L. 1940. Aracnidi raccolte nella Reg. dei Laghi Etiopici della Fossa Galla // Atti della Reale Accademia d'Italia. Vol.11. P.767-873.

Demir H., Seyyar O. 2017. Annotated checklist of the spiders of Turkey // Munis Entomology \& Zoology. Vol.12. No.2. P.433469

Denis J. 1947. Results of the Armstrong College expedition to Siwa Oasis (Libyan desert), 1935. Spiders [Araneae] // Bulletin de la Société Fouad 1er d'Entomologie. Vol.31. P.17-103

Dondale C.D, Redner J.H. 1990. The insects and arachnids of Canada, Part 17. The wolf spiders, nurseryweb spiders, and lynx spiders of Canada and Alaska, Araneae: Lycosidae, Pisauridae, and Oxyopidae // Research Branch Agriculture Canada Publication. No.1856. P.1-383.

El-Hennawy H.K. 2017. A list of Egyptian spiders (revised in 2017) // Serket. Vol.15. No.4. P.167-183.

Fuhn I.E., Niculescu-Burlacu F. 1971. Fam. Lycosidae // Fauna Republicii Socialiste România (Arachnida). Vol.5. No.3. 253 p.

Guy Y. 1966. Contribution à l'étude des araignées de la famille des Lycosidae et de la sous-famille des Lycosinae avec étude spéciale des espèces du Maroc // Travaux de l'Institut Scientifique Chérifien et de la Faculté des Sciences, Série Zoologie, Rabat. Vol.33. P.1-174

Hepner M., Paulus H.F. 2009. Contributions on the wolf spider fauna (Araneae, Lycosidae) of Gran Canaria (Spain) // Bulletin of the British Arachnological Society. Vol.14. P.339-346. doi:10.13156/arac.2009.14.8.339

Lecigne S. 2016. Contribution à la connaissance de l'aranéofaune (Araneae) de Crète (Grèce) et description de la femelle inconnue de Neaetha absheronica Logunov \& Guseinov, 2002 (Salticidae) // Nieuwsbrief van de Belgische Arachnologische Vereniging. Vol.30. No.3. P.95-118.
Logunov D.V. 2012. A synopsis of the genus Zyuzicosa Logunov, 2010 (Aranei: Lycosidae) // Arthropoda Selecta. Vol.21. No. P.349-362.

Logunov D.V., Ponomarev A.V. 2020. Karakumosa gen. nov., a new Central Asian genus of fossorial wolf spiders (Araneae: Lycosidae: Lycosinae) // Revue suisse de Zoologie. T.127. Fasc.2. (in press).

Lucas H. 1838. Arachnides, Myriapodes et Thysanoures // BarkerWebb P., Berthelot S. (eds.). Histoire naturelle des îles Canaries. Paris. T.2. Pt.2. P.19-52.

Nentwig W., Blick T., Bosmans R., Gloor D., Hänggi A., Kropf C. 2020. Spiders of Europe. Version 07.2020. Online at: https:// www.araneae.nmbe.ch, accessed on 9 July 2020. https://doi.org/ $10.24436 / 1$

Otto S. 2020. Caucasian Spiders. A faunistic database on the spiders of the Caucasus. Version 10.2019. Online at: https:// caucasus-spiders.info/, accessed on 19 July 2020.

Pepe R. 2005. Basi zoologiche-naturalistiche del tarantismo nel Salento // Thalassia Salentina. Vol.27 (for 2004). P.47-62.

Pickard-Cambridge O. 1872. General list of the spiders of Palestine and Syria, with descriptions of numerous new species, and characters of two new genera // Proceedings of the Zoological Society of London. Vol.40. No.1. P.212-354.

Pickard-Cambridge O. 1876. Catalogue of a collection of spiders made in Egypt, with descriptions of new species and characters of a new genus // Proceedings of the Zoological Society of London. Vol.44. No.3. P.541-630.

Roewer C.F. 1955a. Katalog der Araneae von 1758 bis 1940, bzw. 1954. 2. Band, Abt. a (Lycosaeformia, Dionycha [excl. Salticiformia]). 2. Band, Abt. b (Salticiformia, Cribellata) (Synonyma-Verzeichnis, Gesamtindex). Institut royal des Sciences naturelles de Belgique, Bruxelles, 1751 pp.

Roewer C.F. 1955b. Die Araneen der Österreichischen Iran-Expedition 1949/50 // Sber. öst. Akad. Wiss. Abt.I. Bd.164. H.9. S.751-782.

Roewer C.F. 1959. Araneae Lycosaeformia II (Lycosidae) // Exploration du Parc National de l’Upemba, Mission G. F. de Witte. Bd.55. S.1-518.

Roewer C.F. 1960a. Araneae Lycosaeformia II (Lycosidae) (Fortsetzung und Schluss) // Exploration du Parc National de l'Upemba, Mission G. F. de Witte. Bd.55. S.519-1040.

Roewer C.F. 1960b. Lycosidae aus Afghanistan (Araneae) // Acta Universitatis Lundensis (N.F.) Afd.2. Vol.56. No.17. S.1-34.

Shorthouse D.P. 2010. SimpleMappr, an online tool to produce publication-quality point maps. Available at http://www. simplemappr.net (accessed on 9 July 2020).

Strand E. 1913. Erste Mitteilung über Spinnen aus Palästina, gesammelt von Herrn Dr J. Aharoni // Archiv für Naturgeschichte. Bd.79. H.A10. S.147-162.

WSC 2020. World Spider Catalog. Version 21.0. Natural History Museum Bern, online at: http://wsc.nmbe.ch, accessed on 9 July 2020. doi: 10.24436/2

Wunderlich J. 1992. Die Spinnen-Fauna der Makaronesischen Inseln: Taxonomie, Ökologie, Biogeographie und Evolution // Beiträge zur Araneologie. Bd.1. S.1-619.

Zamani A., Mirshamsi O., Marusik Yu.M., Moradmand M. 2020. The checklist of the spiders of Iran. Version 2020. Available at http://www.spiders.ir, accessed on 19 July 2020.

Zonstein S.L., Marusik Yu.M. 2013. Checklist of the spiders (Araneae) of Israel // Zootaxa. Vol.3671. No.1. P.001-127. DOI: https://doi.org/10.11646/zootaxa.3671.1.1

Zonstein S.L., Marusik Yu.M., Omelko M.M. 2015. A survey of spider taxa new to Israel (Arachnida: Araneae) // Zoology in the Middle East. Vol.61. No.4. P.372-385. doi:10.1080/ 09397140.2015 .1095525

Responsible editor K.G. Mikhailov 